\title{
Push and Pull Factors and their effects on International Tourists' Revisit Intention to Nepal
}

\author{
Rojan Baniya* \\ Suman Ghimire** \\ Sandip Phuyal ${ }^{* * *}$
}

\begin{abstract}
International tourists are of great prominence to Nepali economy, consequently their motivation to visit Nepal should guide the success of Nepal as tourist destination. The primary objective of this study is to use commonlyrecognized 'integrative models of push and pull motives' to travel motivations of international tourists to Nepal. Based on previous studies, inspecting the direct effect of push and pull motives on international tourists to Nepal, this study proposes that except for 'enhancing social', all the other variables (pull factors - nature, culture and heritage sites, adventure, friendly people climate; push factors relaxation and recreation, enhance relationship, fulfilling practice, escape from daily routine) exhibited encouragingly positive correlation with re-visit intentions among international tourist to Nepal. Additionally, the overall push factors and pull factors together predicted the revisit intention of international tourists to Nepal, however push factor was insignificant. Thus, convincingly, we could say that international tourists are motivated to visit Nepal by its pull factors i.e. destination attributes. The study's findings reveal Nepal's international tourists'impetuses, and provide practitioners and policymakers with a foundation to develop an effective strategy to improve the international tourist based tourism in Nepal.
\end{abstract}

Keyword: push factors, pull factors, motivation, Nepal, tourism, international tourists

\footnotetext{
* Asst. Prof. Rojan Baniya is marketing research and service marketing specialist. His areas of interest are marketing research, service marketing and tourism research. Currently, he is associated with Kathmandu University School of Management as Assistant Professor of Marketing. Email: rojan@kusom.edu.np

** Suman Ghimire is associated with Nepal Tourism Board

*** Sandip Phuyal is doing research on tourism re-visit intention.
} 


\section{Introduction}

Previous profound knowledge in Tourism has established repeat visit to a particular tourist destination as indicative of loyalty towards destinations. And tourist destinations also would depend on these regular and frequent visitors (e.g., Darnell \& Johnson, 2001; Jayaraman et al., 2010). Thus several past researches have already endeavored to find antecedents of destination revisit intentions. These determinants of repeat visit or factors of tourist loyalty holds a special significance for stakeholders of tourism industry because "by understanding the relationships between future behavioral and its determinants, destination tourism managers would know better on how to build up an attractive image and improve their marketing efforts to maximize their use of resources" (Chen \&Tasi, 2007, p. 1116).

Repeat visit is kind of lifeblood for tourism businesses from economic value generation point of view for the destination in consideration. Consistent with popular belief in marketing, motivation pervious customers is way less effortless cost-wise compare to acquiring new ones (Shoemaker \& Lewis, 1999). Past researchers(Weaver \& Lawton, 2002; Lau \&Mckercher, 2004) have established the promotional spending of influencing repeat visitors to be at lower end compare to spending required to bring in noble visitors. Thus, repeat visitors are great saves of marketing spending.

Any business if wants to get into profitability cycle, it should attempt to preserve its loyal customer base (Hsu et al., 2008). Some researchers have gone to the level of demonstrating measurable benefits of customer loyalty. For instance, "previous studies show $2 \%$ increase in customer retention has the same effects on profits in terms of cost cutting by 10\%" (Mat Som et al. 2011, p.178). Malaysia, a well-known tourist destination in Asia relies heavily on repeat visitors to realize increased revenue from tourism(Jayaraman et al. ,2010). Hence, loyalty towards a tourist destination with strength to generate repeat visitors is of interest for any tourist destination.

Establishing the importance of customer loyalty for destination, the curiosity is drawn to the factors that influence loyalty or repeat visit. Various researches have identified various factors such as such as satisfaction (Jang \&Feng, 2007), novelty seeking (Jang \&Feng, 2007), perceived value (Bigne et al., 2009), past vacation experience (Petrik et al., 2001), safety (Chen \&Gursoy, 2001), cultural differences (Reisinger\& Turner, 1998; Chen \&Gursoy, 2001), image (Ross, 1993; Milman\&Pizam, 1995; Yoon \&Uysal, 2005, Chi \&Qu, 2008), motivation and satisfaction (Yoon \&Uysal, 2005), and destination attributes (Chi \&Qu, 2008; Zabkar et al., 2010) as drivers of customer destination loyalty. The purpose of this study is to identify the key factors that affect repeat visitors in Nepal, an uncharted territory till now in terms of research. This study takes a different approach by taking the push and pull factors of motivation as holistic antecedents of travel customers' loyalty. 
The model of motivation with push and pull factors tend to provide holistic approach to identifying antecedents of customer loyalty. Furthermore, "in an increasingly competitive marketplace, the success of marketing destinations should be guided by a through analysis of tourist motivation and its interplay with tourist satisfaction and loyalty" (Yoon \&Uysal, 2005p.45). Established already and popular, intrinsic motivators relating to socio-psychological needs are known as push factors, and external forces originating from features of the destination are the pull factors.

The direct contribution of travel and tourismto GDP was 4\% in 2015, this signifies the importance of travel and tourism sector in Nepal (World Travel and Tourism Council Data, 2016). Thus, travel and tourism sector needs a special attention from everyone residing in Nepal. This study focuses on factors influence repeat visitors, which may provide the ground to improve the Nepali tourism market for repeat visitors. The study may play a significant role by identifying the key antecedentsfrom push and pull motivation factors that affect repeat visit of international tourist in Nepal.

First, this paper presents a brief review of literature regarding the status of tourism industry in Nepal, push and pull motivation factors of motivation,revisit intention and destination loyalty. Second, it outlines the research methodology, then in third part it presents the findings of the research and finally in the last part the managerial implications are presented.

\section{Literature Review}

The importance of tourism sector in Nepalese economy can never be undermined. In fact Nepal Tourism Policy 2009 has recognized tourism as key vehicle for economic and social development. In line with this strategic direction, various policy level effort have been framed to develop and expand tourism activities, to improve quality of tourism services, to increase revenue and to expand tourism based employment opportunities, all directed to enhance the livelihood standard of Nepalese people (Nepal Tourism Policy, 2009). Like most of the nations in the globe, Nepal has also realized the significance of tourism sector in its development.

\section{Status of Tourism in Nepal}

Nepal is able to attracted 790,118 foreign tourists in alone in 2014 mainly from India, P.R. of China, U.S.A., Sri Lanka and U.K earning revenues of around $\$ 471 \mathrm{~m}$ in 2014. Most of the tourist visiting Nepal were from age group 31-45 years of age consisting of 2, 35,738 tourist in year 2014 (Ministry of Culture, Tourism \& Civil Aviation, 2015). In 2014, 3,95,849 tourists visited Nepal for the purpose of holiday/ pleasure; 98,765 for pilgrimage; 97,185 for trekking \& mountaineering; 32,395 for official; 24,494 for business and 13,432 for conferences with the average length of stay of 12.44 days and per day spending of $\$ 48$ per person (Ministry of Culture, Tourism 
\& Civil Aviation, 2015). However, according to Tourism Ministry, the number of tourist arrival at Nepal have declined sharply by $29.7 \%$ to 5,38,970 tourists in 2015 mainly because of 25th April, 2015 devastating earthquake and Tarai protest. Despite the decrease in number of tourists' arrival, the average spending per day per tourist has increased to $\$ 68.5$ and average length of stay has also increased to 13.16 days (Prasain, 2016).

With its ancient cultures and mesmerizing Himalayas, Nepal is one of the ideal destinations for a whole lot of tourists around the world. Authentic experiences of steamy jungles, rafting in spectacular scenery, trekking and mountaineering are few attractions of Nepal as a tourist destination. According to The Travel \& Tourism Competitiveness Report 2015, Nepal is ranked 102th position out of 141 countries surveyed in term of travel and tourism competitiveness. Also, due to stronger US dollar against Nepali currency, which increases the purchasing power of tourists visiting Nepal, Nepal is ranked at 23rd position in term of price competitiveness destination. Although, in worldwide comparison Nepal is enviable position (i.e. 29th in case of the number of World Heritage natural sites, 16th position in terms of the Natural tourism digital demand and $25^{\text {th }}$ ranked in natural resources), it has not been able to leverage its advantage and attract as many tourists as it should have (World Economic Forum, 2015).

\section{Relationship Marketing for Nepal Tourism Industry}

Marketing over the years have grown from developing, selling, and delivering product to mutually satisfying long-term relationship with customers (Buttle, 1996). In true sense, marketing has shifted its paradigm from transactional value to lifetime value of a customer. "In this new perspective, both transactional and relational qualities are combined and strive to establish, maintain, and enhance mutually beneficial relationship with customers so as to satisfy the objectives of all parties" (Nwakanma et al., 2007, p.57). The tourism sector of Nepal needs to focus on this changed paradigm as well. Also data shows, a good chunk of tourists are already revisiting (one third in 2008), thus it is logical to focus on these repeated visitors given the tremendous benefits of repeated visitors.

Several studies have focused on the importance of revisit of tourists as well as determinants of tourists revisit. In the recent study (Thiumsak \& Ruangkanjanases, 2016) conducted in Bangkok, Thailand, several constituentsleading to predicting the intent of international tourists to revisit Bangkok were pinpointed. These findings could be the inspiration behind the improvisation of antecedents of tourist revisit intention, to be incorporated by the destination marketing offices of Thailand. And a similar study done on Singapore showed that those willing to revisit Singapore in future were willing to recommend Singapore to their relatives and friends (Hui, Wan, 
\& Ho, 2007). Thus, those tourists, with revisit intention tend to generate positive word of mouth for the destination. In study conducted at Langkawi Island, Malaysia, repeat visitors tends to stay for longer period of time and were found to be significantly more loyal than first time visitors (Wahida, Alimanb, Hashim, \& Harudinb, 2015). This is indicative of the fact that repeat visitors provide bigger share of wallet and also offers more share in lifetime value.

\section{Factors Affecting Revisit Intention}

Revisiting intention is highly sought out tourist intention by tourism destinations of anykind. Taking into consideration consumption perspective, tourists' exhibit threetypes of behavior at three different stages; pre-visitation, during visitation and post visitation (Rayan, 2002; William and Buswell, 2003). The experiences in these visitationsmotivate tourist for repeat visit. Zabkar (2010) established that destination attributes influenced perceived quality, which then affected satisfaction, and interestingly the latter led to revisit intention. Furthermore, MostafaviShirazi and Mat Som (2010) identifiedrepeat visitation as asign of loyalty in tourist destination that is strongly affected by destination attributes. Chen and Tsai (2007) instituted destination image and satisfaction to be significant variables and behavioral intention strongly affected them. Also, Huamin (2014) found in his study that attitude, perceived behavioral control, and destination image influenced the revisit intention. This study showed that the value tourist get from the visitations influence their revisit intention significantly.

Another study by Som and Marzuki (2012), revealed that the key factors that affect repeat visitors in Sabah, Malaysia were destination image, modern environment, weather and natural attractions. Also, the study assessed the major motives for revisiting of Sabah, Malaysia, which were are relaxation \& recreation, enhance relation, enhance social, fulfilling prestige, and escaping from the daily routine. There is no fixed list of destination attributes and motives to promote revisit intention. Every tourist destination with its uniqueness attracts tourists, and tourists visit or revisit those places for specific purposes. For Nepal also, the study attempts to identify those motivational factors.

\section{Push and Pull Motivation Factors}

Consumer motivation is pivotal to consumer behavior (Swarbrooke\& Horner, 2001: 169), and also is basis of the study is consumer motivation theory. With all reasons, a touristic destination can be envisaged as 'a value proposition' and tourist representing consumers. Just as customer purchase any product or service, he/she goes through similar process. A tourist can't help being affected by wide range of factors that motivate him or her to travel. Several researchers have proposed their own list of motivators like Krippendorf (1987: 8) identified the following eight motivators as tourists' motivation to travel(1). Escape ;(2). Recuperation and regeneration;(3). 
Compensation and social amalgamation; (4). Communication ;(5). Liberty and selfdetermination; (6).Self-realization; (7). Happiness ;(8). Broadening of the mind. Similarly, Swarbrooke and Horner (2001:54) proposed a typology model of motivation categorizing motivators into six types, namely physical motivators(relaxation, suntan, exercise and health, and sex), emotional motivators ( nostalgia, romance, adventure, escapism, fantasy and spiritual fulfillment) personal motivatorsvisiting friends and relatives, making new friends), personal development motivators (increased knowledge and learning new skills), status motivators (exclusivity, fashionability, obtaining a good deal, and ostentatious spending opportunities), cultural motivators ( sightseeing and experiencing new cultures.). Between these two proposed motivators, a commonality is both of them are endogenous i.e. the motivators are outcomes of needs and wants of tourists.

Dann (1977) questioned this proposition, being convinced that tourists' verdict in fact was affected by both internal and external causes. Then Dann (1977) went further to categorize motivators into push factors and pull factors. A clear demarcation was put forward, where pull (e.g. destinations' price, climate, culture etc) factors are supply components from attraction or destinations whereas push factors (e.g. value, belief) was to satisfy need. Based on Dann'smanifesto push factors govern tourist decision "whether to travel" and pull factors assist tourist elect "where to travel". Since then the push and pull factors as the antecedents of tourist motivation has gained popularity among the scholars.

\section{Selecting Pull Factors (Destination Attributes) and Push Factors (Motives)}

There are numerous attributes related with specific destination, it is a daunting tasks to consider all the attributes as determinants of tourist's destination revisit intention. In the context, those attributes that are deemed popular and attractive to tourists could be chosen as destination attributes under consideration. Similar things apply, when we consider endogenous motives to travel as well. There might be countless intrinsic motives to revisit a specific destination. In order to finalize the independent variables for the study, the destination attributes and motives, four relevant studies have been taken into consideration.

In first study, Robert Travers (2004) based on his TRPAP specified that "Nepal's main selling points are by tour operators as mountains (40\%), beautiful nature (40 $\%)$, friendly people (39\%), cultural diversity (37\%) and adventure tourism (22\%)". In further elaboration in the study, Nepal's strengths were discerned as scenic beauty, friendly people, mountains, culture and a low cost base within the country. This study was Nepal specific, thus holds a good basis to select destination attributes for this study. Thus, variables like cultural attractions with heritage sites, climate, and friendly people were assumed to play a significant role in creating positive perception 
and revisiting intention towards Nepal among international travelers.

In the second study, Jain (2013) used attribute sets to study image perception in three groups - the first group was connected Jammu \& Kashmir (J\&K) Tourists Attractions (Destinations \& Spots); the second was associated J\&K Culture, Traditions, Lifestyle and Hospitality; lastly, the third group was related to 'Paradise J\&K. The attribute sets were

1. J\& K Tourists attractions (Destinations and Spots)

Attribute Set: interesting ancient culture, interesting architecture, appealing festivals, beautiful pilgrimage destinations, wildlife centuries and nature, etc.

2. J \& K Culture, Traditions, Lifestyle and Hospitality

Attribute Set: Unique culture, wonderful customs and traditions, interesting rural life style, exciting atmosphere etc.

3. Paradise J \& K.

Attribute Set: Beautiful garden and lakes, Beautiful streams and glaciers, beautiful mountains, interesting natural wonders etc.

The finding of the study revealed that all the destination attributes of J\&K were not perceived negative by tourists; only eleven variables out of thirty seven variables studied did not create positive perception for $\mathrm{J} \& \mathrm{~K}$, rest were found to create positive recognition. This gives a clear indication to J\&K as which attributes should be the focus of promotion.

Similarly, in the third study, R. Rajesh (2013) statedthat destination attributes that built a destination image impacts on tourist perception, destination image and tourist satisfaction on destination loyalty; the variables used by him were travel environments, natural attractions, historical and cultural attractions, accessibility, infrastructure relaxation and price/value. These identified independent variables showed impact on important dependent variables like perception, image and satisfaction.

In the fourth study, Som and Marazuki (2012) producedfactor group, which were modern environment, destination image and weather/natural attractions out of nineteen attributes. The study was conducted for Sabah, Malaysia. Itestablisheddestination image as the most critical destination attribute for repeat tourists, which explained $44.13 \%$ of the variance with 5.29 as eigenvalue.Som and Marazuki (2012) further studied motives for re-vistingSabah, Malaysia. The motives factors were relaxation \&recreation, enhance relation, enhance social, fulfilling prestige, and escaping from the daily routine whereas relaxation and recreation were found to be the most important motive to revisit intention.

Based on these four studies, destination attributes and motives for this study were 
developed. In tabular form, it is shown below:

Table No. 1:

The source of variables

\begin{tabular}{|c|c|c|c|c|}
\hline S.N. & Source & Variables used & $\begin{array}{l}\text { Variables } \\
\text { selected for } \\
\text { this study }\end{array}$ & $\begin{array}{l}\text { Scales selected for } \\
\text { this study }\end{array}$ \\
\hline 1. & $\begin{array}{l}\text { Robert Travers } \\
\text { (2009) }\end{array}$ & $\begin{array}{l}\text { Mountains, beautiful } \\
\text { nature, friendly } \\
\text { people, cultural } \\
\text { diversity, and } \\
\text { adventure tourism }\end{array}$ & $\begin{array}{l}\text { Nature, } \\
\text { friendly } \\
\text { people, } \\
\text { culture, } \\
\text { adventure }\end{array}$ & \multirow{3}{*}{$\begin{array}{l}\text { Destination } \\
\text { attributes: } \\
\text { - Nature, } \\
\text { - Culture } \\
\text { attraction and } \\
\text { Heritage } \\
\text { - Adventure } \\
\text { - Friendly } \\
\text { people, } \\
\text { - Climate }\end{array}$} \\
\hline 2. & Jain (2013) & $\begin{array}{l}\text { Destinations and } \\
\text { spots, culture, } \\
\text { tradition, lifestyle } \\
\text { and hospitality, } \\
\text { beautiful natural } \\
\text { wonders }\end{array}$ & $\begin{array}{l}\text { Culture, } \\
\text { nature }\end{array}$ & \\
\hline 3. & $\begin{array}{l}\text { R. Rajesh } \\
\text { (2013) }\end{array}$ & $\begin{array}{l}\text { Travel environment, } \\
\text { natural attractions, } \\
\text { historical and } \\
\text { cultural attractions, } \\
\text { accessibility, } \\
\text { infrastructure } \\
\text { relaxation, price and } \\
\text { value. }\end{array}$ & $\begin{array}{l}\text { Cultural } \\
\text { attraction }\end{array}$ & \\
\hline 4. & $\begin{array}{l}\text { Som\&Marzuki } \\
\text { (2012) }\end{array}$ & $\begin{array}{l}\text { Destination } \\
\text { image, modern } \\
\text { environment, } \\
\text { weather and natural } \\
\text { attraction, relaxation } \\
\text { \& recreation, } \\
\text { enhance relation, } \\
\text { enhancing social, } \\
\text { fulfilling prestige, } \\
\text { escaping from daily } \\
\text { routine. }\end{array}$ & $\begin{array}{l}\text { Relaxation } \\
\text { \&recreation, } \\
\text { enhance } \\
\text { relation, } \\
\text { enhancing } \\
\text { social, } \\
\text { fulfilling } \\
\text { prestige, } \\
\text { escaping from } \\
\text { daily routine. }\end{array}$ & $\begin{array}{l}\text { Motives: } \\
\text { - } \quad \text { Relaxation \& } \\
\text { recreation, } \\
\text { - } \\
\text { Enhance } \\
\text { relation, } \\
\text { - Enhancing } \\
\text { social, } \\
\text { - Fulfilling } \\
\text { prestige, } \\
\text { - Escaping from } \\
\text { daily routine }\end{array}$ \\
\hline
\end{tabular}




\section{Theoretical Framework and Research Hypotheses}

\section{Theoretical Framework}

From numerous studies exploring destination attributes and motives responsible for revisit intention of tourists, a summarized list of sub-scale for motives (relaxation and recreation, enhance relation, enhancing social, fulfilling prestige and escaping from daily routine) and destination attributes (nature, cultural attraction and heritage, adventure, friendly people and climate) were devised based on studies (Robert Travers,2009, Som\&Marzuki (2012), R. Rajesh (2013), Jain (2013).

\section{The theoretical framework of the study is presented in Figure 1.}

\section{Independent Variables}

\begin{tabular}{l} 
Destination attributes \\
Nature \\
- Culture attraction and Heritage \\
- Criendly People \\
- Climate \\
\hline
\end{tabular}

\section{Motives}

- Relaxation and Recreation

- Enhance Relationship

- Enhancing Social

- Fulfilling Prestige

- Escaping from Daily Routine

\section{Dependent Variables}

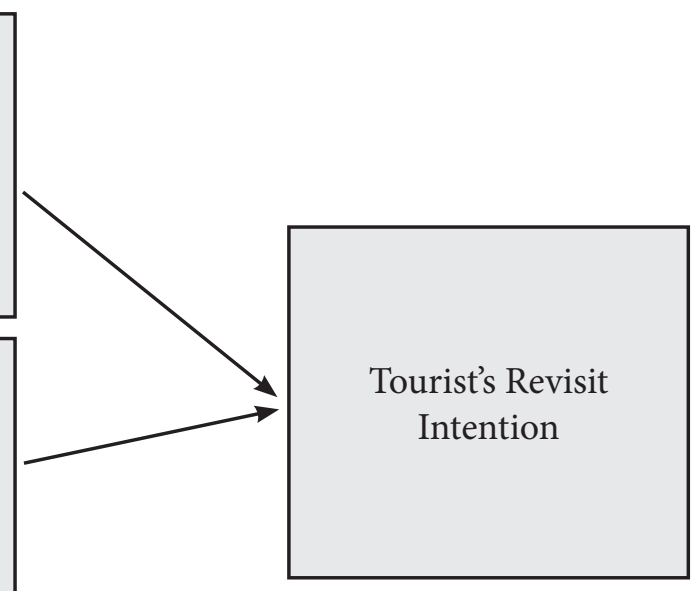

Figure 1: Theoretical Framework

\section{Research Hypotheses}

This study proposed following hypotheses:

H1: Destination Attributes is positively related to tourist revisit intention.

H1a: Nature is positively related to tourist revisit intention.

H1b: Cultural Attraction and Heritage is positively related to tourist revisit intention.

H1c: Adventure is positively related to tourist revisit intention.

H1d: Friendly People is positively related to tourist revisit intention. 
H1e: Climate is positively related to tourist revisit intention.

$\mathrm{H} 2$ : Motives is positively related to tourist revisit intention.

$\mathrm{H} 2 \mathrm{a}$ : Relaxation and Recreation is positively related to tourist revisit intention.

$\mathrm{H} 2 \mathrm{~b}$ : Enhance Relationship is positively related to tourist revisit intention.

$\mathrm{H} 2 \mathrm{c}$ : Enhancing Social is positively related to tourist revisit intention.

H2d: Fulfilling Prestige is positively related to tourist revisit intention.

H2e: Escape from Daily Route is positively related to tourist revisit intention.

\section{Method}

\section{Sample and procedure}

A self-administered survey questionnaire was created to discern factors influencing repeat visitation to Nepal. The target population of this study was international touristsvisiting Nepal. The survey instrument was developed mainly with an aim to identify the underlying dimensions of visitors' revisit intention. A convenience sampling approach was employed to collect data in January 2016 at different tourist centers and places including Tribhuvan International Airport, Kathmandu, Nepal Tourism Board of Kathmandu \&Pokhara and some touristic locations in Kathmandu within Nepal. Among 300 self-administered questionnaires distributed, a total of 200 usable questionnaires were obtained representing $67 \%$ of response rate.

This study made use of a self-administered survey with four distinct parts gathering information on distinct travel characteristics and demographic variables of the respondents, destination attributes, travel motives, and tourists' revisit intention. The first part posed respondents' background; the demographic profiles included age, gender, income, education, occupation and nationality, and their purpose of visit.In the second part, respondents were asked to express their agreement with statements about destination attributes and their intention to revisit Nepal. In the third part of the questionnaire, respondents were asked to indicate their agreement with statements describing their motives for revisiting Nepal. The attribution items, motives and revisit intentions were assessed, using a 7-point Likert scale from $7=$ strongly disagree to $1=$ strongly agree.

First, the findings were profiled by socio-demographic and travel characteristics. Second, a scale reliability analysis using Chornbach alpha was run to identify underlying internal consistency among the statement of constructs as they were borrowed from other studies. Thirdly, correlation and regression analysis were carried out to investigate the relationship between dependent and independent variables of the study. Cronbach's alpha was used to assess the reliability of each scale. The alpha 
coefficient of the scales ranged from .712 (PS) to .999 (NT).

\section{Results}

Mean, standard deviation, Pearson correlation coefficients between study variables as well as their mean, standard deviation, and internal consistency reliability (Cronbach's alpha) are shown in the Table 1.

Table 1: Pull and Its Components - Mean, Standard Deviation, Correlation matrix, and Cronbach's alpha

\begin{tabular}{|l|l|l|l|l|l|l|l|l|l|l|}
\hline & & Mean & SD & $\mathbf{1}$ & $\mathbf{2}$ & $\mathbf{3}$ & $\mathbf{4}$ & $\mathbf{5}$ & $\mathbf{6}$ & $\mathbf{7}$ \\
\hline 1 & RI & 5.83 & 1.12 & .806 & & & & & & \\
\hline 2 & NT & 5.79 & 1.07 & $.544^{\star *}$ & .999 & & & & & \\
\hline 3 & CHS & 5.30 & 1.14 & $.456^{\star *}$ & $.556^{\star *}$ & .999 & & & & \\
\hline 4 & ADV & 5.71 & 1.22 & $.543^{\star *}$ & $.671^{\star *}$ & $.573^{\star *}$ & .999 & & & \\
\hline 5 & FP & 5.80 & 1.16 & $.597^{\star *}$ & $.662^{\star *}$ & $.656^{\star *}$ & $.726^{\star *}$ & .999 & & \\
\hline 6 & CL & 5.24 & 1.24 & $.425^{\star *}$ & $.621^{\star *}$ & $.562^{\star *}$ & $.549^{\star *}$ & $.597^{\star *}$ & .999 & \\
\hline 7 & PL & 5.57 & .97 & $.638^{\star *}$ & $.845^{\star *}$ & $.800^{\star *}$ & $.851^{\star *}$ & $.871^{\star *}$ & $.804^{\star *}$ & .889 \\
\hline
\end{tabular}

Note:

$$
{ }^{* *} \mathrm{p}<.01
$$

RI - Revisit Intention, NT - Nature, CHS - Culture and Heritage Sites, ADV Adventure, FP - Friendly People, CL - Climate, PL - Pull Factors

Cronbach's alpha shown in diagonal

The above result indicates all the relationships between different study variables are significant and in the expected directions.

Table 2: Pull and Its Components - Mean, Standard Deviation, Correlation matrix, and Cronbach's alpha

\begin{tabular}{|c|c|c|c|c|c|c|c|c|c|c|}
\hline & & Mean & SD & 1 & 2 & 3 & 4 & 5 & 6 & 7 \\
\hline 1 & RI & 5.83 & 1.13 & .806 & & & & & & \\
\hline 2 & $\mathrm{RR}$ & 5.48 & 0.98 & $.533^{\star *}$ & .999 & & & & & \\
\hline 3 & ER & 4.81 & 1.24 & $.383^{* *}$ & $.483^{* *}$ & .995 & & & & \\
\hline 4 & ES & 3.42 & 1.87 & .150 & $.239^{* *}$ & $.447^{\star *}$ & .995 & & & \\
\hline 5 & FS & 5.30 & 1.29 & $.336^{* *}$ & $.461^{\star *}$ & $.429^{\star *}$ & $.318^{\star *}$ & .999 & & \\
\hline 6 & EDR & 4.88 & 1.72 & $.164^{\star *}$ & $.274^{* *}$ & $.233^{\star *}$ & $.318^{\star *}$ & $.435^{\star *}$ & 999 & \\
\hline 7 & PS & 4.79 & 1.00 & $.417^{\star *}$ & $.623^{* *}$ & $.701^{\star *}$ & $.729^{* *}$ & $.735^{\star *}$ & $.685^{\star *}$ & .712 \\
\hline
\end{tabular}

Note: ${ }^{\star *} \mathrm{p}<.01$

RI - Revisit Intention, RR - Relaxation and Recreation, ER - Enhance Relationship, ES - Enhance Social, FS - Fulfilling Prestige, EDR - Escape Daily Routine, PS - Push 


\section{Factors}

Cronbach's alpha shown in diagonal

The above result indicates that except for RI and ES, all the relationships between different study variables are significant and in the expected directions.

\section{Building Predictive Models}

Table 3: Relationship between Push, Pull and Revisit Intentions

\begin{tabular}{|l|l|l|l|l|l|}
\hline $\begin{array}{c}\text { Predictor Variable } \\
\text { (Revisit Intentions) }\end{array}$ & \multicolumn{1}{|c|}{ B } & \multicolumn{1}{|c|}{ SE B } & $\boldsymbol{\beta}$ & $\boldsymbol{t}$ & $\boldsymbol{p}$ \\
\hline Constant & .903 & .485 & & 1.863 & .064 \\
\hline Pull Factors & .792 & .097 & .605 & 8.171 & .000 \\
\hline Puss Factors & .099 & .086 & .086 & 1.155 & .250 \\
\hline
\end{tabular}

Multiple regression analysis was used to test if the pull factors and push factors significantly predicted international tourist' revisit intention. The results of the regression indicated the two predictors explained $42.8 \%$ of the variance $\left(\mathrm{R}^{2}=.428\right.$, $\mathrm{F}=53.467, \mathrm{p}<.01)$. It was found that pull factors significantly predicted revisit intentions $(\beta=.605, \mathrm{p}<.01)$, push factors did not $(\beta=.086, \mathrm{p}>.01)$. The results show that revisit intention has significant positive relationships with pull factors, however there is no relationship between revisit intentions and push factors. This indicates that pull motives is significant predictor of international tourist' revisit intention to Nepal.

Table 4: Relationship between Pull Factors - Destination Attributes factors and Revisit Intentions

\begin{tabular}{|l|l|l|l|l|l|}
\hline \multicolumn{1}{|c|}{$\begin{array}{c}\text { Predictor Variable } \\
\text { (Revisit Intentions) }\end{array}$} & \multicolumn{1}{|c|}{ B } & \multicolumn{1}{|c|}{ SE B } & $\boldsymbol{\beta}$ & $\boldsymbol{t}$ & $\boldsymbol{p}$ \\
\hline Constant & .948 & .462 & & 2.051 & .042 \\
\hline Nature & .251 & .102 & .210 & 2.452 & .015 \\
\hline Culture and Heritage & .031 & .085 & .030 & .360 & .720 \\
\hline Adventure & .209 & .087 & .210 & 2.418 & .017 \\
\hline Friendly People & .338 & .099 & .313 & 3.424 & .001 \\
\hline Climate & .014 & .076 & .014 & .179 & .858 \\
\hline
\end{tabular}

Multiple regression analysis was used to test if the pull factors (namely, nature, culture and heritage, adventure, friendly people and climate)significantly predicted international tourist' revisit intention. The outcome of the regression analysisshowed the five predictors elucidated $44.1 \%$ of the variance in international tourists' revisit intention. $\left(\mathrm{R}^{2}=.441, \mathrm{~F}=24.14, \mathrm{p}<.01\right)$. It was found that climate $(\beta=.21, \mathrm{p}<.01)$, 
adventure $(\beta=.21, \mathrm{p}<.001)$ and friendly people $(\beta=.31, \mathrm{p}<.01)$ significantly predicted international tourist' revisit intention, whereas culture and heritage, and climate did not.The results show that the revisit intentions of international tourists' has significant positive relationships with nature, adventure and friendly people, however there is no relationships between revisit intention and culture and heritage and climate. This indicates that nature, adventure and friendly people are significant predictor of international tourist' revisit intention to Nepal.

\section{Discussion}

This study examined the influence of push and pull factors on international tourist' revisit intention of Nepal. The study contributes to overall understanding to why international tourists would plan to revisit Nepal. Drawing from the conceptual structure of push and pull theory from Dann (1977), the revisit intent of international tourists were assessed both in terms of their socio-psychological variables, widely known as push factors and destination attributes of Nepal also known as pull factors. In the initial correlation analysis, except for enhancing social factor, all the other variables showed positive correlation with re-visit intentions.

In further analysis, the overall push factors and pull factors together predicted the revisit intention of international tourists to Nepal, however push factor was found to be insignificant. Thus, conclusively, we could say that international tourists are motivated to visit Nepal by its pull factors i.e. destination attributes. Within pull factors, when regression was run, it was found that nature, adventure and friendly people were the three significant reasons that motivated international tourists to revisit Nepal. The findings stand as a significant contribution to tourist destination loyalty studies. The results, which were devised on the basis of multiple regression analysis, show the imperative constituentswith significant positive influence on the tourists' revisit intention to Nepal. The significant predictors are destination attributes namely nature, adventure, and friendly people.

The finding of the study is consistent with Prayag's 2009 study, where destination image is a significant predictor towards the revisit intention. Definitely, the positive image influences the tourists to have more tendencies to revisit and recommend the destination to others. Similarly, Nepal's pull factors could attract international tourist to revisit again and again. Also the study is consistent with findings of Cape Town study (Zhou, 2005) on the destination attributes attracting international tourists. The study showed most of the destination attributes showed a significantly positive correlation with the decision on destination choice. However, the attitude of local people does not show a significant effect on the decision. On contrary, in this study friendly people were one of the significant predictors of tourist revisit intention.

Hence, destination managers and other tourism promoting bodies like Nepal 
Tourism Board should improve destination image of Nepal, which impact loyalty of repeat visitors. Chen and Tsai (2007) exhibited that "endeavors to build or improve the image of a destination facilitate loyal visitors revisiting or recommending behaviors..." (p.1121), which is imperative to success of any destination.

\section{Implications}

Owing to the concept destination loyalty, this study clearly exhibits that repeat visitors aspire to revisit Nepal as a holiday destination in future. When established destination attributes that institute Nepal as a tourist destinations in the eyes of international tourists were examined, showed that those destination attributes were the indispensable factors for repeat visitors of Nepal. In other words, it seems friendliness of local people, adventure and nature are the main destination attributes that manifest Nepal's image as a tourist destination motivating repeat visit among international tourists.Consequently, the concerned authorities Nepal Tourism Board and other governing bodies, managers associated with various destinations within Nepal, processionals working in tourism in Nepal should consider destination attributes that demonstrate Nepal as a worthy repeat tourism place to intensify destination loyalty and gain much needed competitive advantages.

\section{Limitations and Suggestions for Future Research}

This study has several limitations that need to be addressed in future research. First, all the study variables were captured from self-reported measures and therefore self-report bias cannot be ruled out. Second, the samples for this study were drawn from service stations where international tourists could be found. Small sample size, drawn from various tourists' service centers creates doubt on the representativeness of the sample. Nonetheless, the findings of this study are in both in line and also in contrast with the findings of the studies carried out in the different cultural contexts suggesting that though revisit intentions can be predicted by push and pull factors. Further replication of this study in Nepali cultural context is advised to enhance the reliability of this study.

This study may be replicated with samples fromall over Nepal so as to validate the findings of present study. Future studies could also examine the moderating role of other variables in the relationships between push and pull factors and international tourists' revisit intention. With complete concentration on repeat visit motivation of international visitors, it is advised that future research investigate frequent domestic travelers to unravel factors that influence their revisit intention to address the growing importance of domestic tourism nowadays. 


\section{References}

Bigne, J. E., Sanchez, I., \&Andreu, L. (2009). The role of variety seeking in short and long run revisit intentions in holiday destinations. International Journal of Culture, Tourism and Hospitality Research, 3(2),103-115.

Buttle, F. (1996).Relationship marketing: theory and practice. Sage Publications Ltd.

Chen, C. F., \& Tsai, D. (2007). How destination image and evaluative factors affect behavioural intentions? Tourism Management, 28, 1115-1122.

Chen, C. F., \& Tsai, D. C. (2007). How destination image and evaluative factors affect behavioral intentions? Tourism management, 28(4), 1115-1122.

Retrieved from

http://dx.doi.org/10.1016/j.tourman.2006.07.007

Chen, J. S., \&Gursoy, D. (2001). An investigation of tourists destination loyalty and preferences. International Journal of Contemporary Hospitality Management, 13(2), 79-85.

Retrieved from

http://dx.doi.org/10.1108/09596110110381870

Chi, C., \&Qu, H. (2008).Examining the structural relationships of destination image, tourist satisfaction and destination loyalty: an integrated approach.Tourism Management, 29, 624-636.

Dann,G.M.S. (1977). Anomie, ego-enhancement and tourism.Annals of Tourism Research, vol. 4, no. 4, pp. 184-194.

Darnell, A. C., \& Johnson, P. S. (2001). Repeat visits to attractions: a preliminary economic analysis. Tourism Management, 22, 119-126.

Hsu, C., Killion, L., Brown, G., Gross, M., \& Huang, S. (2008). Tourism marketing: An Asian-Pacific perspective. Milton, Australia: John Wiley \& Sons.

Hui, T. K., Wan, D., \& Ho, A. (2007). Tourists' satisfaction, recommendation and revisiting Singapore. Tourism management, 28(4), 965-975.

Jain, D. (2013). Visitors' Perception Of Destination Image-A Case Study Of J\&K Tourism. Prestige International Journal Of Management \& IT-Sanchayan, 2(1), 91.

Jang, S., \&Feng, R. (2007).Emporal destination revisit intention: the effects of novelty seeking and satisfaction. Tourism Management, 28, 580-90.

Jayarman, K., Lin, S. K., Guat, C. L., \&Ong, W. L. (2010). Does Malaysian Tourism Attract Singaporeans to Revisit Malaysia? Journal of Business and Policy Research, 5(2), 159-179. 
Krippendorf, (1987). The Holiday Makers.Understanding the Impact of Leisure and Travel. Oxford: Butterworth Heinemann.

Lau, A. L. S., \&McKercher, B. (2004). Exploration versus acquisition: A comparison of first-time and repeat visitors. Journal of Travel Research, 42(3), 279-285.

Retrieved from

http://dx.doi.org/10.1177/0047287503257502

Mat Som, A. P., MostafaviShiazi, S. F., Marzuki, A., \&Jusoh, J. (2011).A critical analysis of tourist satisfaction and destination loyalty.Journal of Global Management, 2(1), 178-183.

Milman, A., \&Pizam, A. (1995). The role of awareness and familiarity with a destination: The central Florida case. Journal of Travel Research, 33(3), 21-27.

Retrieved from

http://dx.doi.org/10.1177/004728759503300304

MostafaviShirazi, S. F., \& Mat Som, A. P. (2010). Relationship Marketing and Community Involvement: Two Significant Factors for Tourism Strategies. In C.A. Brebbia\& F.D. Pineda (Eds.), Sustainable Tourism IV (pp. 47-53). Southampton, UK: WIT Press.

Retrieved from

http://dx.doi.org/10.2495/ST100051

Nwakanma, H., Jackson, A. S., \&Burkhalter, J. N. (2007). Relationship Marketing: An Important Tool For Success In The Marketplace. Journal of Business \& Economics Research (JBER), 5(2), 55-64.

Petrick, J. F., Morais, D. D., \& Norman, W. C. (2001).An examination of the determinants of entertainment vacationers' intentions to revisit.Journal of Travel Research, 40(1), 41-48.

Retrieved from

http://dx.doi.org/10.1177/004728750104000106

Rajesh, R., \&Madhuri, S. (2013). Study of socio-economic impacts of tourism development on Daulatabad village.In A Journal of World heritagen Tourism Congress (ITC) , 2(1), 22-34.

Rayan, C. (2002). From motivation to assessment. In Ryan, C. (Ed.), The tourist experience (pp. 58-77). London: Continuum.

Reisinger, Y.\& Turner, L. (1998). Cross-cultural differences in tourism: A strategy for tourism marketers. Journal of Travel \& Tourism Marketing, 7(4), 79-106. 
Retrieved from

http://dx.doi.org/10.1300/J073v07n04_05

Ross, G. F. (1993). Ideal and actual images of backpacker visitors to Northern Australia.Journal of Travel Research, 32(2), 54-57.

Retrieved from

http://dx.doi.org/10.1177/004728759303200208

Shoemaker, S., \& Lewis, R. C. (1999). Customer loyalty: The future of hospitality marketing. International Journal of Hospitality Management, 18, 345-370.

Som, A. P. M., Marzuki, A., Yousefi, M., \&AbuKhalifeh, A. N. (2012). Factors influencing visitors' revisit behavioral intentions: a case study of Sabah, Malaysia. International Journal of marketing studies, 4(4), 39.

Swarbrooke, J. \& Horner, S. (2001). Consumer Behavior in Tourism.Oxford: Linacre House.

Thiumsak, T., \&Ruangkanjanases, A. (2016).Factors Influencing International Visitors to Revisit Bangkok, Thailand.Journal of Economics, Business and Management, 4(3).

Travers, Robert. (2004). Tourism Marketing Strategy for Nepal 2005-2020.Tourism for Rural Poverty Alleviation Programme (TRPAP).

Wahid, S. D. M., Aliman, N. K., Hashim, S. M., \&Harudin, S. (2016). First-time and Repeat Visitors to Langkawi Island, Malaysia. Procedia Economics and Finance, 35, 622-631.

Weaver, D., \& Lawton, L. (2002). Tourism Management (2nd ed.). Milton, Qld: Jhon Wiley \& Sons Australia, Ltd.

Williams, C., \&Buswell, J. (2003).Service quality in leisure and tourism.CABI.

Retrieved from

http://dx.doi.org/10.1079/9780851995410.0000

Yoon, Y., \&Uysal, M. (2005). An examination of the effects of motivation and satisfaction on destination loyalty: a structural model. Tourism Management, 26(1), 45-56.

Zabkar,V., Brenc, M., \&Dmitrovic, T. (2010). Modelling perceived quality, visitor satisfaction and behavioural intentions at the destination level. Tourism Management, 31, 537-546.

Retrieved from

http://dx.doi.org/10.1016/j.tourman.2009.06.005

Zhou, L. (2005). Destination attributes that attract international tourist to Cape Town. Faculty of Economic and Management Sciences, University of the Western Cape, pp. 22-61. 


\section{ANNEX I \\ QUESTIONNAIRE}

\section{Dear Respondent,}

The below mentioned questionnaire is for research purpose related to study on Factors Affecting Tourist Revisiting Intention of Nepal. Please tick your response for the following questions. Your time and effort to complete this survey will be appreciated. The information you provide will be kept confidential and will only be used for research purpose.
a) Gender:
b) Age:
c) Annual Income:
d) Education: 1) Intermediate
2) Bachelors
3) Masters
4) Above Masters
e) Nationality:

1. Occupation: 1) Professional 2) Government Employee 3) Private Sector Employee 4) Self Employed 5) Business Owner 6) Student 7) Others

2. Nepal - Times of Visit (Please Select One)
1) First time
2) Second times
3) Third times
4) More than three times

3. Main Purpose of Visit (Please Select One)
1) Holiday and Pleasure
2) Trekking \& Mountaineering
3) Pilgrimage
4) Business
5) Convention/Conference
6) Others

1. Regarding your perception of attributes of Nepal, please show your level of agreement or disagreement with the following statements.

\begin{tabular}{|c|l|c|c|c|c|c|c|c|c|}
\hline & & $\begin{array}{c}\text { Strongly } \\
\text { Disagree }\end{array}$ & & & & \multicolumn{2}{|c|}{$\begin{array}{c}\text { Strongly } \\
\text { Agree }\end{array}$} \\
\hline 1 & $\begin{array}{l}\text { Nepal is a destination for Natural } \\
\text { attractions so as called Naturally Nepal. }\end{array}$ & 1 & 2 & 3 & 4 & 5 & 6 & 7 \\
\hline 2 & $\begin{array}{l}\text { Nepal is vigorously rich in diversity of } \\
\text { natural resources. }\end{array}$ & 1 & 2 & 3 & 4 & 5 & 6 & 7 \\
\hline 3 & $\begin{array}{l}\text { Mountains and its landscapes thrill our } \\
\text { excitement. }\end{array}$ & 1 & 2 & 3 & 4 & 5 & 6 & 7 \\
\hline 4 & $\begin{array}{l}\text { There are many more interesting natural } \\
\text { wonders such as Waterfalls. }\end{array}$ & 1 & 2 & 3 & 4 & 5 & 6 & 7 \\
\hline
\end{tabular}




\begin{tabular}{|c|l|c|c|c|c|c|c|c|}
\hline & \multicolumn{2}{|c|}{$\begin{array}{c}\text { Strongly } \\
\text { Disagree }\end{array}$} & & & \multicolumn{3}{|c|}{$\begin{array}{c}\text { Strongly } \\
\text { Agree }\end{array}$} \\
\hline 5 & $\begin{array}{l}\text { Interesting festivals and jatras (ritual } \\
\text { performance). }\end{array}$ & 1 & 2 & 3 & 4 & 5 & 6 & 7 \\
\hline 6 & $\begin{array}{l}\text { Interesting celebrations from the } \\
\text { diversified communities }\end{array}$ & 1 & 2 & 3 & 4 & 5 & 6 & 7 \\
\hline 7 & Beautiful heritage sites & 1 & 2 & 3 & 4 & 5 & 6 & 7 \\
\hline 8 & $\begin{array}{l}\text { The Trekking routes are amazingly } \\
\text { beautiful and adventurously thrilling. }\end{array}$ & 1 & 2 & 3 & 4 & 5 & 6 & 7 \\
\hline 9 & I can enjoy mount climbing. & 1 & 2 & 3 & 4 & 5 & 6 & 7 \\
\hline 10 & I can enjoy river rafting. & 1 & 2 & 3 & 4 & 5 & 6 & 7 \\
\hline 11 & I can enjoy with rural lifestyle. & 1 & 2 & 3 & 4 & 5 & 6 & 7 \\
\hline 12 & $\begin{array}{l}\text { I have memorable traditional hospitality } \\
\text { and diversified of local food. }\end{array}$ & 1 & 2 & 3 & 4 & 5 & 6 & 7 \\
\hline 13 & $\begin{array}{l}\text { Nepali people are ever welcoming \& } \\
\text { smiling. }\end{array}$ & 1 & 2 & 3 & 4 & 5 & 6 & 7 \\
\hline 14 & $\begin{array}{l}\text { I can enjoy pleasant climate in all } \\
\text { seasons. }\end{array}$ & 1 & 2 & 3 & 4 & 5 & 6 & 7 \\
\hline 15 & $\begin{array}{l}\text { The relaxing atmosphere is for good } \\
\text { health to me. }\end{array}$ & 1 & 2 & 3 & 4 & 5 & 6 & 7 \\
\hline 16 & $\begin{array}{l}\text { The wonderful sightseeing opportunities } \\
\text { will be available in most of the places in } \\
\text { all seasons. }\end{array}$ & 1 & 2 & 3 & 4 & 5 & 6 & 7 \\
\hline
\end{tabular}

2. Regarding your intention or motives to visit Nepal, please express your level of agreement or disagreement with following statements

\begin{tabular}{|c|l|c|c|c|c|c|c|c|}
\hline & \multicolumn{2}{|c|}{$\begin{array}{c}\text { Strongly } \\
\text { Disagree }\end{array}$} & & & \multicolumn{3}{|c|}{$\begin{array}{c}\text { Strongly } \\
\text { Agree }\end{array}$} \\
\hline 1 & To relax physically & 1 & 2 & 3 & 4 & 5 & 6 & 7 \\
\hline 2 & To relax spiritually & 1 & 2 & 3 & 4 & 5 & 6 & 7 \\
\hline 3 & To participate in new activities & 1 & 2 & 3 & 4 & 5 & 6 & 7 \\
\hline 4 & To thrill and excite & 1 & 2 & 3 & 4 & 5 & 6 & 7 \\
\hline 5 & To sightseeing touristic spots & 1 & 2 & 3 & 4 & 5 & 6 & 7 \\
\hline 6 & To appreciate natural resources & 1 & 2 & 3 & 4 & 5 & 6 & 7 \\
\hline 7 & To meet new people & 1 & 2 & 3 & 4 & 5 & 6 & 7 \\
\hline
\end{tabular}




\begin{tabular}{|c|l|c|c|c|c|c|c|c|}
\hline & \multicolumn{1}{|c|}{$\begin{array}{c}\text { Strongly } \\
\text { Disagree }\end{array}$} & & & \multicolumn{3}{|c|}{$\begin{array}{c}\text { Strongly } \\
\text { Agree }\end{array}$} \\
\hline 8 & $\begin{array}{l}\text { To enhance communication with local } \\
\text { community }\end{array}$ & 1 & 2 & 3 & 4 & 5 & 6 & 7 \\
\hline 9 & To visit friend and relatives & 1 & 2 & 3 & 4 & 5 & 6 & 7 \\
\hline 10 & To exchange customs and traditions & 1 & 2 & 3 & 4 & 5 & 6 & 7 \\
\hline 11 & $\begin{array}{l}\text { To live or stay temporarily with local } \\
\text { community }\end{array}$ & 1 & 2 & 3 & 4 & 5 & 6 & 7 \\
\hline 12 & To increase social status & 1 & 2 & 3 & 4 & 5 & 6 & 7 \\
\hline 13 & $\begin{array}{l}\text { To visit a destination that would impress } \\
\text { my friends and family }\end{array}$ & 1 & 2 & 3 & 4 & 5 & 6 & 7 \\
\hline 14 & $\begin{array}{l}\text { To satisfy the desire to be somewhere } \\
\text { else }\end{array}$ & 1 & 2 & 3 & 4 & 5 & 6 & 7 \\
\hline 15 & $\begin{array}{l}\text { To fulfill dream of visiting a foreign } \\
\text { land/country }\end{array}$ & 1 & 2 & 3 & 4 & 5 & 6 & 7 \\
\hline 16 & $\begin{array}{l}\text { To have enjoyable time with my travel } \\
\text { companion(s) }\end{array}$ & 1 & 2 & 3 & 4 & 5 & 6 & 7 \\
\hline 17 & To be away from home & 1 & 2 & 3 & 4 & 5 & 6 & 7 \\
\hline 18 & To seek solitude in a foreign land & 1 & 2 & 3 & 4 & 5 & 6 & 7 \\
\hline
\end{tabular}

3. Circle the number that represents your feeling towards revisiting Nepal as Tourist Destination.

\begin{tabular}{|c|l|c|c|c|c|c|c|c|c|}
\hline & & $\begin{array}{l}\text { Strongly } \\
\text { Disagree }\end{array}$ & & & \multicolumn{3}{|c|}{$\begin{array}{c}\text { Strongly } \\
\text { Agree }\end{array}$} \\
\hline 1 & $\begin{array}{l}\text { I am willing to return to Nepal in the } \\
\text { future. }\end{array}$ & 1 & 2 & 3 & 4 & 5 & 6 & 7 \\
\hline 2 & $\begin{array}{l}\text { I am willing to recommend Nepal to } \\
\text { family and friends as a holiday destina- } \\
\text { tion. }\end{array}$ & 1 & 2 & 3 & 4 & 5 & 6 & 7 \\
\hline 3 & $\begin{array}{l}\text { I have wonderful image of Nepal as a } \\
\text { holiday destination. }\end{array}$ & 1 & 2 & 3 & 4 & 5 & 6 & 7 \\
\hline 4 & $\begin{array}{l}\text { I feel I am very loyal to Nepal as a desti- } \\
\text { nation choice. }\end{array}$ & 1 & 2 & 3 & 4 & 5 & 6 & 7 \\
\hline
\end{tabular}

